\title{
Pengukuran Tingkat Kepuasan dan Loyalitas Pelanggan terhadap Toko Ritel Kosmetik Make Over di Surabaya
}

\author{
Meutia Fatha Aulia dan Berto Mulia Wibawa \\ Departemen Manajemen Bisnis, Institut Teknologi Sepuluh Nopember (ITS) \\ e-mail: berto@mb.its.ac.id
}

\begin{abstract}
Abstrak-Semakin banyaknya produk kosmetik yang beredar membuat pelanggan memiliki lebih banyak alternatif, sehingga akan lebih sulit untuk mendapat kepuasan yang dapat menimbulkan loyalitas pelanggan terhadap suatu merek atau toko. Penelitian ini bertujuan untuk mengukur tingkat kepuasan dan loyalitas pelanggan terhadap setiap format toko ritel Make Over untuk memberikan rekomendasi strategi pemasaran yang dapat meningkatkan dan mempertahankan loyalitas pelanggan. Penelitian ini dilakukan menggunakan pendekatan kuantitatif dan data didapatkan dari kuesioner kepada 150 responden dengan penyebaran kuesioner secara langsung (direct survey) ke toko-toko Make Over di pusat perbelanjaan di Kota Surabaya. Berdasarkan perhitungan ACSI dan CLI, pelanggan yang mengunjungi toko ritel Make Over baik Single-Brand Store dan Multi-Brand Store dirasa sudah puas dan loyal. Penelitian ini juga merumuskan implikasi manajerial yang dapat diterapkan oleh Make Over sebagai referensi tambahan untuk meningkatkan kualitas pelayanan di toko ritelnya dengan fokus pada peningkatan kepuasan untuk Independent Store serta peningkatan kepuasan dan kepercayaan untuk Multi-Brand Store, memaksimalkan customer in-store experience dan customer recovery, serta pembuatan loyalty dan membership program untuk meningkatkan frekuensi pembelian ulang.
\end{abstract}

Kata Kunci-Makeup, Kosmetik,Kepuasan, Loyalitas,ACSI, CLI

\section{PENDAHULUAN}

$\mathrm{I}$ NDUSTRI kosmetik di Indonesia terus meningkat dari tahun ke tahun seiring dengan perkembangan zaman dan gaya hidup masyarakat yang terus berubah dimana produk kecantikan seperti skincare dan makeup merupakan kebutuhan fisiologis dari pelanggan perempuan [1]. Saat ini, terdapat terdapat ribuan produk kosmetik yang telah memiliki izin edar. Hingga akhir September 2019, peredaran kosmetik di Indonesia mencapai 49.598 produk atau sekitar 60,7 persen dari total peredaran produk Obat dan Makanan [2]. Banyaknya alternatif produk kosmetik yang dapat dipilih oleh pelanggan membuat para pemasar semakin sulit untuk memuaskan mereka. Selain itu, adanya dukungan dari kemudahan akses informasi yang mengakibatkan semakin tingginya tingkat kecerdasan dan pengetahuan pelanggan akan suatu produk sehingga tingkat kesadaran mereka akan harga dan kualitas produk yang ditawarkan semakin meningkat. Hal ini dapat membuat pelanggan untuk sulit bersikap loyal hanya terhadap satu merek kosmetik. Tingkat kesulitan untuk memuaskan pelanggan juga semakin bertambah dikarenakan munculnya berbagai macam saluran (channel) bagi perusahaan untuk memasarkan produknya baik secara online maupun offline atau yang biasa disebut sebagai penjualan ritel. Pada tahun 2019 ini, bisnis ritel pada segmen kesehatan dan kecantikan diperkirakan akan meningkat sebesar 30 persen, bahkan pada semester pertama tahun 2019 ini pertumbuhan bisnis ritel kesehatan dan kecantikan sudah mencapai 20 persen (yoy) [3]. Diantara produk kesehatan dan kecantikan yang dijual melalui ritel, pertumbuhan bisnis ritel pada produk kosmetik, perawatan kulit (skin care) dan perawatan diri (personal care) mengalami peningkatan dengan nilai pertumbuhan ritel kosmetik memiliki nilai yang paling tinggi yaitu 6,2 persen pada tahun 2016, 6,4 persen pada tahun 2017, dan 6,5 persen pada tahun 2018. Tingkat penjualan ritel kosmetik yang semakin meningkat menandakan peningkatan persaingan pada ritel kosmetik sehingga membuat para pemasar produk kosmetik untuk lebih memperhatikan strategi pemasaran untuk setiap toko ritelnya.

Make Over, yang memiliki beberapa format toko ritel, juga menghadapi permasalahan ini. Make Over merupakan salah satu merek unggulan yang dimiliki PT Paragon Technology and Innovation. Merek ini sekarang sudah menjadi top of mind brand dikalangan pecinta make up, Make Up Artist (MUA), bahkan masyarakat umum. Make Over sudah memperkuat mereknya sebagai merek Make Up Profesional [4]. Make Over memiliki beberapa channel penjualan offline berupa singlebrand store atau yang biasa disebut dengan Independent Retail Store. Selain itu, terdapat multi-brand stores yang merupakan toko ritel yang mengoperasikan beberapa merek dalam satu toko ritel dimana Make Over juga memiliki toko ritel jenis ini berupa Department Store (Matahari Departement Store) dan Health and Beauty Store (Guardian, Watsons, dsb). Di Kota Surabaya sendiri Make Over memiliki 2 (dua) Independent Retail Store yang terletak di Tunjungan Plaza 6 dan Pakuwon Mall Trade Center dan 1 (satu) gerai di Matahari Departement Store [5]. Selain itu, Make Over juga terdapat di setiap Health and Beauty Store khususnya Guardian dan Watson yang ada di pusat perbelanjaan di Kota Surabaya.

Make Over merupakan merek yang sudah sangat dikenal merupakan salah satu merek kosmetik lokal yang paling digemari oleh perempuan Indonesia [6]. Oleh karena itu, memiliki retail store merupakan hal yang sangat penting untuk meningkatkan kepercayaan dan akan mendukung loyalitas pelanggan karena penggunaan toko ritel sebagai saluran penjualan offline dapat mendukung citra suatu merek dan akan memberikan pengaruh positif terhadap merek tersebut [7]. 
Melihat hal ini, maka penelitian mengenai pengukuran kepuasan dan loyalitas pelanggan yang mengunjungi toko ritel Make Over di Surabaya dianggap perlu dilakukan agar dapat diketahui tingkat kepentingan masing-masing atribut kepuasan dan loyalitas untuk dapat melakukan perbaikan, serta dapat diukur tingkat kepuasan dan loyalitas pelanggan dari kedua format toko ritel yang dimiliki.

\section{LANDASAN TEORI}

\section{A. Pemasaran Ritel (Retail Marketing)}

Pemasaran memiliki tujuan menarik pelanggan baru dengan menawarkan nilai yang unggul dan untuk menjaga pelanggan yang telah ada dengan menyampaikan nilai dan kepuasan [8]. Pengalaman pelanggan dapat dilakukan melalui sarana atau alat yang menyediakan pengalaman bagi pelanggan atau experience provider dimana salah satu aspeknya adalah aspek lingkungan yang salah satu pengaplikasiannya yaitu pada toko ritel [9].

Toko ritel merupakan salah satu sarana penyedia pengalaman bagi pelanggan. Dalam suatu proses penciptaan pengalaman, pelanggan diberikan kesempatan untuk merasakan, berpikir, bertindak, dan berhubungan dengan produk yang dipromosikan [10]. Pelanggan juga diharapkan untuk memiliki memori yang menyenangkan tentang pengalaman mereka dengan suatu produk, sehingga menghasilkan peningkatan kesadaran akan produk dan nilai produk dimana nilai pelanggan akan suatu produk yang lebih tinggi akan mengarah pada kepuasan pelanggan yang lebih tinggi [10].

\section{B. Kepuasan Pelanggan (Customer Satisfaction)}

Kepuasan pelanggan merupakan rasa senang atau kecewa yang muncul karena membandingkan kinerja yang dipikirkan terhadap kinerja yang diharapkan [11]. Tingkat kepuasan akan terbentuk saat suatu merek atau produk dapat memenuhi kebutuhan pelanggan [12]. Dalam konteks ritel, kepuasan pelanggan merupakan hasil dari evaluasi subjektif dimana alternatif (toko ritel) yang dipilih sesuai atau melebihi harapan pelanggan [13]. Pelanggan yang merasa puas tersebut biasanya mendapat kesan yang positif dari produk dan pelayanan yang ditawarkan di toko tersebut.

\section{Loyalitas Pelanggan (Customer Loyalty)}

Loyalitas adalah suatu kesediaan pelanggan untuk melanjutkan pembelian pada sebuah perusahaan dalam jangka waktu yang panjang dan mempergunakan produk atau jasa secara berulang dan secara sukarela merekomendasikan kepada orang lain [14] .

\section{Industri Kosmetik}

Kosmetik adalah adalah bahan atau sediaan yang dimaksudkan untuk digunakan pada bagian luar tubuh manusia (epidermis, rambut, kuku, bibir dan organ genital bagian luar) atau gigi dan membran mukosa mulut terutama untuk membersihkan, mewangikan, mengubah penampilan dan/atau memperbaiki bau badan atau melindungi atau memelihara tubuh pada kondisi baik [15].

\section{E. Format Toko Ritel (Retail Store Format)}

Di negara berkembang seperti Indonesia, toko ritel biasa dikelola dalam bentuk single-brand stores dan multi-brand stores [16]. Single-brand specialty stores merupakan toko ritel yang hanya menjual dan mengoperasikan satu merek saja sedangkan multi-brand stores merupakan toko ritel yang menawarkan beberapa merek dalam tingkat lingkungan toko yang tinggi dan menampilkan posisi, citra, dan nilai dari suatu merek [16].

\section{METODE PENELITIAN}

\section{A. Desain Penelitian}

Sifat penelitian ini adalah penelitian descriptive dengan pendekatan kuantitatif untuk mengetahui tingkat kepuasan dan loyalitas pelanggan di toko ritel Make Over Surabaya.

\section{B. Sampel dan Metode Pengumpulan Data}

Teknik sampling yang digunakan dalam penelitian ini adalah teknik non-probability sampling. Sampel berjumlah 150 responden yang lolos dari tahap screening sehingga kuesioner yang diisi relevan dengan keadaan responden. Sampel pada penelitian ini adalah perempuan yang dibagi menjadi 2 kategori yaitu pelanggan Make Over di Surabaya yang megunjungi toko ritel Make Over dan berada di toko tersebut minimal 5 menit untuk Independent Retail Store dan Department Store dan untuk Health and Beauty Store yaitu pelanggan Make Over di Surabaya yang pernah mengunjungi dan melakukan pembelian pada Guardian dan Watsons. Kriteria responden dalam penelitian ini adalah pelanggan perempuan dari produk Make Over di Surabaya berumur 18-59 tahun yang membeli produk Make Over pada secara langsung di toko ritel atau telah melakukan pembelian di HABA Store pada 3 bulan terakhir.

\section{Metode Analisis Data}

Berikut ini merupakan metode analisis yang digunakan pada penelitian ini:

\section{1) American Customer Satisfaction Index (ACSI)}

ACSI memiliki validitas prediktif yang lebih besar dibandingkan dengan ukuran kepuasan pelanggan lainnya [17]. Skor ACSI didapat melalui penilaian terhadap haparan, kinerja, dan kepuasan pelanggan. Poin harapan merepresentasikan sejauh mana produk atau layanan yang diberikan memenuhi harapan dari pelanggan, kemudian poin kinerja merepresentasikan seberapa baik produk atau layanan yang diberikan jika dibandingkan dengan tipe ideal yang dimiliki pelanggan, dan poin kepuasan merepresentasikan seberapa puas pelanggan terhadap produk dan layanan yang diberikan secara keseluruhan [17]. Berikut ini merupakan rumus yang digunakan dalam mengukur tingkat kepuasan pelanggan dengan ACSI.

Setelah analisis ACSI dilakukan, akan didapatkan hasil tingkat kepuasan pelanggan Make Over khususnya yang mengunjungi dan melakukan pembelian di toko ritel Make Over. Hasil dari CSI (1) berupa persentase milai dari 0 hingga yang tertinggi 100 persen.

$$
\mathrm{CSI}=((\text { Kepuasan-1) } * .3885+(\text { Expectancy }-1) * .3190+
$$

(Kinerja-1)* .2925) / $9 * 100$

Berikut ini atribut kepuasan yang menjadi variabel penelitian ACSI [18].

2) Customer Loyalty Index (CLI)

Customer Loalty Index (CLI) adalah sebuah metode penelitian yang digunakan untuk mengetahui tingkat loyalitas 
pelanggan terhadap suatu produk atau jasa. Penelitian ini menggunakan CLI (2) untuk menganalisis tingkat loyalitas pelanggan Make Over khususnya yang mengunjungi dan melakukan pembelian di toko ritel Make Over. Berikut ini adalah rumus untuk mengetahui tingkat loyalitas pelanggan.

$$
C L I=\frac{\sum_{i}^{n} 1(\text { Willing Statement }) \times 100 \%}{N}
$$

Setelah perhitungan CLI dilakukan, maka akna diperoleh hasil tingkat loyalitas pelanggan. Berikut adalah rentang skala dan kriteria dan Customer Loyalty Index.

Berikut ini variabel penelitian CLI yang digunakan dalam penelitian ini [13].

\section{ANALISIS DAN DISKUSI}

\section{A. Analisis American Customer Satisfaction Index (ACSI)}

Berikut ini hasil dan analisis nilai ACSI untuk kedua format toko ritel.

\section{1) ACSI untuk Single-Brand Store}

Nilai ACSI untuk Single-Brand Store diperoleh dari pengolahan data kuesioner yaitu penilaian terhadap harapan (expectancy), kinerja, dan kepuasan pelanggan yang mengunjungi Independent Store Make Over di Surabaya. Berikut ini merupakan pengolahan data kuesioner untuk memperoleh nilai ACSI pada Single-Brand Store (Tabel 1).

Berdasarkan hasil perhitungan American Customer Satisfaction Index (ACSI) didapatkan nilai ACSI sebesar 64,75 persen. Nilai 64,75 persen berada pada rentang 61-80 persen yang dapat diinterpretasikan bahwa pelanggan yang mengunjuni Independent Store Make Over merasa puas. Nilai indeks kepuasan tersebut dirasa sudah baik karena harapan dari pelanggan Make Over belum terpenuhi sepenuhnya dilihat dari hasil rata-rata tertimbang dari kinerja dan kepuasan yaitu masing-masing 6,68 yang masih berada dibawah hasil rata-rata tertimbang harapan yaitu 7,15 (Tabel 1). Tetapi, hasil perhitungan menunjukkan bahwa pelanggan Make Over yang mengunjungi Independent Store Make Over merasa setuju bahwa mereka merasa secara keseluruhan cukup puas atas pelayanan yang telah diberikan.

Dari keseluruhan atribut kepuasan,nilai paling rendah dimiliki oleh variabel responsiveness. Pelanggan Make Over yang mengunjungi Independent Store merasa bahwa penanganan keluhan oleh beauty assistant di Independent Store Make Over masih kurang. Berdasarkan observasi langsung yang dilakukan, hanya terdapat satu beauty assistant yang melayani pelanggan sehingga pelayanan yang diberikan kepada setiap pelanggan yang mengunjungi Independent Store menjadi kurang maksimal. Selain itu, karena hanya terdapat satu beauty assistant pada setiap Independent Store membuat beauty assistant harus melayani semua pelanggan yang datang satu per satu sehingga pelanggan tidak mendapatkan pelayanan yang cepat. Hal ini dapat diatasi dengan mengalokasikan lebih banyak beauty assistant pada setiap Independent Store dan memberikan training khusus terkait penanganan keluhan dan pelayanan yang cepat dan tanggap. Oleh karena itu, meskipun hasil indeks kepuasan sudah menunjukkan nilai yang baik, perbaikan harus terus dilakukan agar tingkat kepuasan pelanggan pun semakin meningkat.
Tabel 1.

Nilai ACSI untuk Single-Brand Store

\begin{tabular}{ccccc}
\hline \hline Variabel & Indikator & Expectancy & Kinerja & Kepuasan \\
\hline Tangibility & SI1 & 7.15 & 6.58 & 6.60 \\
Courtsey & SI2 & 7.25 & 6.64 & 6.67 \\
Responsiveness & SI3 & 6.97 & 6.44 & 6.39 \\
Reliability & SI4 & 6.99 & 6.49 & 6.50 \\
$\begin{array}{c}\text { Competence } \\
\text { SI5 }\end{array}$ & SI6 & 7.15 & 6.58 & 6.65 \\
$\begin{array}{c}\text { Credibility, Feel } \\
\text { Secure, Access, }\end{array}$ & SI8 & 7.18 & 6.85 & 6.85 \\
$\begin{array}{c}\text { Communication } \\
\text { and }\end{array}$ & SI9 & 7.31 & 6.69 & 6.67 \\
$\begin{array}{c}\text { Understand the } \\
\text { Customers }\end{array}$ & SI10 & 7.32 & 6.97 & 7.03 \\
& SI11 & 7.13 & 6.72 & 6.75 \\
Rata-Rata & SI12 & 7.13 & 6.56 & 6.53 \\
\hline \hline
\end{tabular}

2) ACSI untuk Multi-Brand Store

Nilai ACSI untuk Multi-Brand Store diperoleh dari pengolahan data kuesioner yaitu penilaian terhadap harapan (expectancy), kinerja, dan kepuasan pelanggan yang mengunjungi Independent Store Make Over di Surabaya. Berikut ini merupakan pengolahan data kuesioner untuk memperoleh nilai ACSI pada Multi-Brand Store (Tabel 2).

Berdasarkan hasil perhitungan American Customer Satisfaction Index (ACSI) didapatkan nilai ACSI sebesar 58,23 persen. Nilai 58,23 persen berada pada rentang 41-60 persen yang dapat diinterpretasikan bahwa pelanggan yang mengunjungi Multi-Brand Store seperti Guardian, Watsons, dan Matahari Departement Store Make Over merasa cukup puas. Nilai indeks kepuasan tersebut dirasa cukup baik karena harapan dari pelanggan Make Over belum terpenuhi sepenuhnya dilihat dari hasil rata-rata tertimbang dari kinerja dan kepuasan yaitu masing-masing 6,10 persen dan 6,14 persen yang masih berada dibawah hasil rata-rata tertimbang harapan yaitu 6,49 (Tabel 2). Hasil perhitungan menunjukkan bahwa pelanggan Make Over yang mengunjungi Multi-Brand Store seperti Guardian, Watsons, dan Matahari Departement Store merasa setuju bahwa mereka secara keseluruhan merasa cukup puas atas pelayanan yang telah diberikan namun tingkat kepuasannya masih lebih rendah dibandingkan Single-Brand Store (Independent Store).

Dari keseluruhan atribut kepuasan,nilai paling rendah dimiliki oleh variabel tangibility. Kenyamanan saat berbelanja merupakan salah satu hal yang penting bagi pelanggan, baik dari lingkungan, atmosfer, dan tata letak produk di toko tersebut. Berdasarkan pengamatan langsung oleh peneliti dibeberapa toko seperti Guardian, Watsons, dan Matahari Departement Store setiap toko memiliki lingkungan, atmosfer dan tata letak yang berbeda atau tidak terstandarisasi dimana terdapat beberapa toko dengan lingkungan dan tata letak yang lebih baikd ari toko lainnya. Hal ini mungkin dapat disebabkan oleh segmentasi pengunjung pada setiap pusat perbelanjaan 
Tabel 2.

Nilai ACSI untuk Multi-Brand Store

\begin{tabular}{ccccc}
\hline \hline Variabel & Indikator & Expectancy & Kinerja & Kepuasan \\
\hline Tangibility & SI1 & 6.09 & 5.88 & 6.06 \\
Courtsey & SI2 & 6.35 & 5.92 & 6.01 \\
Responsiveness & SI3 & 6.19 & 5.69 & 5.72 \\
Reliability & SI4 & 6.51 & 6.02 & 6.06 \\
Competence & SI6 & 6.52 & 6.07 & 6.14 \\
& SI7 & 6.53 & 6.04 & 6.02 \\
Credibility, Feel & SI8 & 6.68 & 6.20 & 6.22 \\
$\begin{array}{c}\text { Secure, Access, } \\
\text { Communication, }\end{array}$ & SI9 & 6.75 & 6.53 & 6.50 \\
and Understand & SI10 & 6.55 & 6.12 & 6.14 \\
the Customers & SI11 & 6.54 & 6.22 & 6.28 \\
& SI12 & 6.57 & 6.28 & 6.30 \\
Rata-Rata & & 6.59 & 6.24 & 6.26 \\
\hline \hline
\end{tabular}

yang berbeda. Hal ini dapat diatasi dengan menetapkan standar tata letak dan properti yang digunakan pada setiap toko menyesuaikan dengan preferensi kenyamanan pelanggan. Oleh karena itu, meskipun hasil indeks kepuasan sudah menunjukkan nilai yang baik, perbaikan harus terus dilakukan agar tingkat kepuasan pelanggan pun semakin meningkat.

\section{B. Analisis Customer Loyalty Indes (CLI)}

Berikut ini hasil dan analisis nilai ACSI untuk kedua format toko ritel.

\section{1) CLI untuk Single-Brand Store}

Nilai CLI untuk Single-Brand Store diperoleh dari pengolahan data masing-masing atribut loyalitas yang terdiri dari attitudinal loyalty dan behavioral loyalty dengan menghitung mean yang disebut sebagai willing statement. Berikut ini merupakan pengolahan data kuesioner untuk memperoleh nilai CLI pada Single-Brand Store (Tabel 3).

Hasil perhitungan Customer Loyalty Index (CLI) pelayanan di Independent Store Make Over yang diperoleh sebesar 70,78 persen yang mendekati angka 71 yang berada pada rentang 7190 persen. Nilai ini diinterpretasikan sebagai pelanggan yang mengunjungi Independent Store saat ini adalah termasuk loyal. Semua indikator CLI menunjukkan indeks yang cukup tinggi, dengan indikator AL2 memiliki indeks paling tinggi yang menunjukkan bahwa pelanggan tidak segan untuk mengatakan hal-hal positif tentang Independent Store Make Over kepada orang lain. Hal tersebut menggambarkan bahwa apa yang dilakukan Make Over untuk pelayanan di Independent Storenya saat ini dapat membuat pelanggan merasa puas dan loyal. Sedangkan indeks terendah dimiliki indikator BL2 yaitu berniat untuk terus melakukan pembelian di Independent Store Make Over yang dikunjungi. Hal tersebut menunjukkan meskipun pengguna merasa puas terhadap pelayanan di Independent Store Make Over, namun niat untuk terus melakukan pembelian di Independent Store lebih rendah yang diindikasikan karena masih banyak alternatif lain yang menyediakan produk yang
Tabel 3.

Nilai CLI untuk Single-Brand Store

\begin{tabular}{|c|c|c|c|}
\hline Kode & Indikator Loyalitas & $\begin{array}{c}\text { Willing } \\
\text { Statement }\end{array}$ & CLI $(\%)$ \\
\hline AL1 & $\begin{array}{l}\text { Merekomendasikan toko ritel } \\
\text { Make Over yang dikunjungi } \\
\text { disetiap kesempatan }\end{array}$ & 3.47 & 69.44 \\
\hline AL2 & $\begin{array}{l}\text { Mengatakan hal-hal positif } \\
\text { tentang toko ritel Make Over yang } \\
\text { dikunjungi kepada orang lain }\end{array}$ & 3.75 & 75.00 \\
\hline AL3 & $\begin{array}{l}\text { Berpendapat bahwa toko ritel } \\
\text { Make Over yang dikunjungi } \\
\text { adalah pilihan terbaik }\end{array}$ & 3.57 & 71.39 \\
\hline BL1 & $\begin{array}{l}\text { Melakukan mayoritas pembelian } \\
\text { di toko ritel make Over yang } \\
\text { dikunjungi }\end{array}$ & 3.47 & 69.44 \\
\hline BL2 & $\begin{array}{l}\text { Berniat untuk terus melakukan } \\
\text { pembelian di toko ritel Make } \\
\text { Over yang dikunjungi }\end{array}$ & 3.43 & 68.61 \\
\hline Total & & \multicolumn{2}{|c|}{70.78} \\
\hline
\end{tabular}

sama. Untuk menjaga loyalitas pelanggan, saat ini Make Over telah melakukan beberapa strategi promosi seperti promo khusus di Independent Store dan mengadakan event-event seperti beauty class dan talkshow yang khusus diadakan di Independent Store. Meskipun begitu, Make Over tetap perlu untuk mengembangkan program-program baru unruk meningkatkan nilai di mata pelanggan sehingga dapat lebih meningkatkan loyalitas pelanggan.

\section{2) CLI untuk Multi-Brand Store}

Nilai CLI untuk Single-Brand Store diperoleh dari pengolahan data masing-masing atribut loyalitas yang terdiri dari attitudinal loyalty dan behavioral loyalty dengan menghitung mean yang disebut sebagai willing statement. Berikut ini merupakan pengolahan data kuesioner untuk memperoleh nilai CLI pada Multi-Brand Store (Tabel 4).

Hasil perhitungan Customer Loyalty Index (CLI) pelayanan di Multi-Brand Store Make Over seperti Guardian, Watsons, dan Matahari Departement Store yang diperoleh sebesar 72,60 persen yang berada pada rentang 71-90 persen. Nilai ini diinterpretasikan sebagai pelanggan yang mengunjungi MultiBrand Store saat ini adalah termasuk loyal. Semua indikator CLI menunjukkan indeks yang cukup tinggi, dengan indikator AL2 memiliki indeks paling tinggi yang menunjukkan bahwa pelanggan tidak segan untuk mengatakan hal-hal positif tentang Multi-Brand Store Make Over kepada orang lain. Hal tersebut menggambarkan bahwa apa yang dilakukan Make Over untuk pelayanan di Multi-Brand Storenya saat ini dapat membuat pelanggan merasa puas dan loyal. Sedangkan indeks terendah dimiliki indikator BL2 yaitu berniat untuk terus melakukan pembelian di Multi-Brand Store Make Over yang dikunjungi. Hal tersebut menunjukkan meskipun pengguna merasa puas terhadap pelayanan di Multi-Brand Store Make Over, namun niat untuk terus melakukan pembelian di Multi-Brand Store lebih rendah yang diindikasikan karena masih banyak alternatif lain yang menyediakan produk yang sama. Untuk menjaga loyalitas pelanggan, saat ini Make Over telah melakukan beberapa strategi promosi seperti promo pada pembelian produk kedua dan promo diskon untuk produk tertentu. 
Meskipun begitu, Make Over tetap perlu untuk mengembangkan program-program baru unruk meningkatkan nilai di mata pelanggan sehingga dapat lebih meningkatkan loyalitas pengguna.

\section{KESIMPULAN DAN SARAN}

\section{A. Kesimpulan}

Dari hasil perhitungan American Customer Satisfaction Index (ACSI) didapatkan nilai ACSI untuk Single-Brand Store sebesar 64,75 persen dan beradap apda rentang 61-80 persen sehingga dapat diinterpretasikan bahwa pelanggan yang mengunjungi Independent Store Make Over merasa puas terhadap layanan dan produk yang tersedia di Independent Store Make Over. Selain itu terdapat nilai ACSI untuk MultiBrand Store sebesar 58,23 persen yang berada pada rentang 4160 persen sehingga dapat dikatakan bahwa pelaggan yang mengunjungi toko ritel Make Over di Guardian, Watsons, dan Matahari Department Store merasa cukup puas dengan pelayanan dan produk yang tersedia. Sedangkan hasil perhitungan Customer Loyalty Index (CLI) pada Single-Brand Store yaitu sebesar 70,78 persen yang mendekati rentang 71-90 persen sehingga dapat dikatakan bahwa pelanggan Make Over yang mengunjungi Independent Store saat ini adalah termasuk loyal. Kemudian untuk hasil perhitungan Customer Loyalty Index (CLI) pada Multi-Brand Store yaitu sebesar 72,60 persen yang berada pada rentang 71-90 persen sehingga dapat dikatakan bahwa pelanggan Make Over yang mengunjungi Multi-Brand Store Make Over seperti Guardian, Watsons, dan Matahari Department Store saat ini adalah termasuk loyal. Meskipun begitu, Make Over tetap perlu untuk mengembangkan program dan strategi pemasaran yang baru untuk meningkatkan value dimata pelanggan sehingga dapat lebih meningkatkan kepuadan dan loyalitas pelanggan.

\section{B. Keterbatasan dan Saran Penelitian}

Penelitian ini telah dilakukan berdasarkan metode penelitian yang digunakan. Namun, penelitian ini tentu tidak akan terlepas dari adanya keterbatasan. Pengumpulan data pada penelitian ini yang awalnya 2 minggu diperpanjang menjadi 4 minggu dikarenakan jumlah responden belum memenuhi target minimum. Pada pengumpulan data, responden diberikan tautan kuesioner bukan langsung mengisi kuesioner pada saat itu karena kondisi lokasi yang kurang kondusif. Pada penelitian ini, tidak dilakukan perubahan struktur kalimat pada kuesioner sehingga menimbulkan tidak adanya pembuktian representasi data yang dikumpulkan dengan kondisi sebenarnya. Kemudian, atribut yang digunakan dalam mengukur tingkat kepentingan dan kepuasan juga diadopsi dari penelitian sebelumnya yang merupakan atribut kepuasan pada penyedia jasa kecantikan high end di India. Atribut kepuasan yang digunakan dalam American Customer Satisfaction Index tidak dilakukan penyesuaian dengan kondisi atribut kepuasan toko ritel kosmetik yang sesuai untuk pelanggan di Indonesia.

Dari keterbatasan yang ada pada penelitian ini, saran yang dapat diberikan untuk penelitian selanjutnya antara lain memperluas cakupan dengan mempertimbangkan untuk menambahkan jenis toko ritel Make Over yang diteliti, karena saat ini Make Over memiliki beragam jenis toko untuk memasarkan produknya sehingga sampel akan dapat lebih cepat
Tabel 4.

Nilai CLI untuk Multi-Brand Store

\begin{tabular}{|c|c|c|c|}
\hline Kode & Indikator Loyalitas & $\begin{array}{c}\text { Willing } \\
\text { Statement }\end{array}$ & CLI $(\%)$ \\
\hline AL1 & $\begin{array}{l}\text { Merekomendasikan toko ritel } \\
\text { Make Over yang dikunjungi } \\
\text { disetiap kesempatan }\end{array}$ & 3.65 & 73.09 \\
\hline AL2 & $\begin{array}{l}\text { Mengatakan hal-hal positif tentang } \\
\text { toko ritel Make Over yang } \\
\text { dikunjungi kepada orang lain }\end{array}$ & 3.81 & 76.12 \\
\hline AL3 & $\begin{array}{l}\text { Berpendapat bahwa toko ritel } \\
\text { Make Over yang dikunjungi } \\
\text { adalah pilihan terbaik }\end{array}$ & 3.58 & 71.65 \\
\hline BL1 & $\begin{array}{l}\text { Melakukan mayoritas pembelian } \\
\text { di toko ritel make Over yang } \\
\text { dikunjungi }\end{array}$ & 3.58 & 71.65 \\
\hline BL2 & $\begin{array}{l}\text { Berniat untuk terus melakukan } \\
\text { pembelian di toko ritel Make Over } \\
\text { yang dikunjungi }\end{array}$ & 3.53 & 70.50 \\
\hline Total & & \multicolumn{2}{|c|}{72.60} \\
\hline
\end{tabular}

untuk mencapai target. Dalam pembuatan kuesioner, penelitian selanjutnya dapat melakukan analisis terlebih dahulu terkait struktur kalimat yang digunakan, terutama pada kuesioner yang diadopsi dari penelitian terdahulu yang merupakan jurnal internasional sehingga perlu untuk diterjemahkan kedalam Bahasa Indonesia, sehingga responden tidak mengalami kebingungan dan data yang diperoleh dapat lebih sesuai dengan keadaan sebenarnya. Untuk atribut kepuasan, dapat dilakukan penyesuaian terlebih dahulu dengan kondisi perilaku pembelian pelanggan di Indonesia.

\section{DAFTAR PUSTAKA}

[1] N. U. Ramadhani, B. M. Wibawa, and J. Gunawan, "Analisis Sikap Konsumen Perempuan terhadap Produk Green Skincare: Pendekatan Multiatribut Fishbein," J. Sains dan Seni ITS, vol. 8, no. 1, pp. 32-36, 2019.

[2] BPOM, "Statistik Produk Yang Mendapat Persetujuan Izin Edar," 2019.

[3] Bisnis.com, "Bisnis Ritel Kesehatan \& Kecantikan Diproyeksi Tumbuh $30 \%$ Tahun Ini," 2019.

[4] Swa.co.id, "Make Over Perkuat Diri sebagai Brand Make up Profesional," 2018.

[5] Make Over, "Store Location," 2019.

[6] Highlight Media, "10 Merek Kosmetik Lokal Indonesia Paling Favorit Untuk Paras Cantikmu," 2018.

[7] J. Semeijn, A. C. R. Van Riel, and A. B. Ambrosini, "Consumer evaluations of store brands: effects of store image and product attributes," J. Retail. Consum. Serv., vol. 11, no. 4, pp. 247-258, 2004.

[8] C. D. Pranindya, B. M. Wibawa, and J. Gunawan, "Pengaruh Social Media Marketing Efforts (SMME) Terhadap Ekuitas Merek dan Respon Konsumen: Studi Kasus Zap Clinic,” J. Sains dan Seni ITS, 2019.

[9] F. Andreani, "Experiential marketing (sebuah pendekatan pemasaran)," $J$. Manaj. Pemasar., vol. 2, no. 1, 2009.

[10] M.-Y. Wu and L.-H. Tseng, "Customer satisfaction and loyalty in an online shop: An experiential marketing perspective," Int. J. Bus. Manag., vol. 10 , no. 1 , p. 104, 2015.

[11] W. B. Amrta, I A D T, "Determinan Perilaku Niat, Kepuasan, dan Loyalitas Berlangganan Layanan Streaming Musik Berbayar: Studi Kasus Spotify Indonesia,” J. Sains dan Seni ITS, 2019.

[12] R. Chinomona and D. Dubihlela, "Does customer satisfaction lead to customer trust, loyalty and repurchase intention of local store brands? The case of Gauteng Province of South Africa," Mediterr. J. Soc. Sci., vol. 5, no. 9, p. 23, 2014.

[13] O. Kamran-Disfani, M. K. Mantrala, A. Izquierdo-Yusta, and M. P. Martínez-Ruiz, "The impact of retail store format on the satisfactionloyalty link: An empirical investigation," J. Bus. Res., vol. 77, pp. 14-22, 2017.

[14] A. Y. Safitri, B. M. Wibawa, and D. S. Ardiantono, "Pengukuran 
Kepuasan dan Loyalitas Konsumen terhadap Kualitas Layanan Taksi Resmi Bandar Udara Juanda Surabaya," J. Sains dan Seni ITS, vol. 8, no. 1, pp. 1-7, 2019.

[15] BPOM, "Peraturan Kepala Badan Pengawas Obat dan Makanan Republik Indonesia Nomor 11 Tahun 2017 Tentang Kriteria dan Tata Cara Penarikan dan Pemusnahan Kosmetika," 2017.

[16] M. Miao, "Do the different store formats of the same brand matter to
Chinese customers? An International study on a Japanese fashion brand," J. Glob. Fash. Mark., vol. 10, no. 1, pp. 18-34, 2019.

[17] Verint, "ACSI (American Customer Satisfaction Index) Score \& Its Calculation," 2013. .

[18] P. Khan and A. Tabassum, "Service quality and customer satisfaction of the beauty-care service industry in Dhaka: a study on high-end women's parlors," J. Bus. Dev. Nations, vol. 12, p. 33, 2010. 